\title{
URGENCY FOR LEGAL FRAMEWORK ON DRONES: LESSONS FOR INDONESIA, INDIA, AND THAILAND
}

\author{
Ridha Aditya Nugraha, ${ }^{*}$ Deepika Jeyakodi** and Thitipon Mahem $^{* * *}$
}

* German Aviation Research Society; ** Spectrum Law Associates, Chennai, India; ***DD Karnyotha LLP

\section{Article Info}

Received : 22 February 2016 | Received in revised form : 9 June 2016 | Accepted : 16 August 2016

Corresponding author's e-mail : r.a.nugraha@unmail.leidenuniv.nl; deepikajey@gmail.com; thitipon.m@gmail.com

\begin{abstract}
Civilian drones are revolutionizing the skies, ushering in several beneficial possibilities and along with it several questions. From checking damage to a roof and aerial photography to border patrolling and emergency response, drones are increasingly put to civil and commercial use. Such a common use requires regulation. Technology has always grown exponentially, whereas the law governing such technology has to contend with such growth. Developed western countries are not the only ones grappling with reigning in these drones. The unique geographic conditions and national interests of Indonesia, India, and Thailand, find more utility for civilian drones, welcoming in the technology and the disruption it brings along. Each of these nations has adopted a measure of regulation for civilian usage of drones, which is the subject of this paper; An overview of its impact on this burgeoning phenomenon is provided, by comparing the existing legal framework in these three countries. Further, an attempt has been made to draw out suggestions for the Governments by highlighting factors that will require more deliberation in the process of establishing a sound legal and regulatory environment for civilian drones. Finally, the possibility of regional co-operation in establishing uniform standards, practices, and legal framework is explored.
\end{abstract}

Keywords: drones, legal framework, regulation, regional co-operation, UAV

\begin{abstract}
Abstrak
Kehadiran pesawat nirawak (drone - dalam konteks ini untuk penggunaan sipil) dengan berbagai kemungkinan manfaat barunya, yang tentunya disertai munculnya isu-isu (hukum) terkait, telah mengubah dunia. Penggunaannya, dimulai dari sekedar mengecek kerusakan pada loteng rumah dan memotret lingkungan sekitar hingga untuk patroli wilayah perbatasan maupun keadaan darurat, telah menguatkan keberadaan pesawat nirawak baik untuk penggunaan sipil maupun komersial. Tentunya diperlukan peraturan terkini sehubungan pengaturan penggunaan pesawat nirawak. Mengingat teknologi tersebut berkembang begitu pesat, hukum-pun harus mampu mengimbanginya; dimana saat ini tidak hanya negara maju saja yang berupaya menyinkronkan keberadaan pesawat nirawak kedalam hukum positifnya. Perkembangan teknologi tersebut juga dimanfaatkan oleh Indonesia, India, dan Thailand mengingat keunikan kondisi geografis beserta kepentingan nasionalnya. Ketiga negara tersebut telah menerapkan berbagai kebijakan unik dalam mengadopsi peraturan mengenai pesawat nirawak, yang mana akan menjadi subjek pembahasan artikel ini. Suatu gambaran mengenai dampak dari fenomena pesawat nirawak akan disajikan dengan membandingkan hukum positif dari tiga negara tersebut. Kemudian, berbagai pertimbangan dan saran mengenai perancangan peraturan pesawat nirawak yang ditujukan kepada pemerintah ketiga negara tersebut akan turut disajikan. Pada akhirnya wacana akan kemungkinan terbentuknya kerjasama regional, tepatnya dalam hal menciptakan standar, praktek, maupun hukum positifyang seragam akan dieksplorasi.
\end{abstract}

Kata kunci: kerjasama regional, kerangka hukum, peraturan, pesawat nirawak, UAV 


\section{Introduction}

In 1782, when the Montgolfier brothers first set unmanned aerostats afloat in preparation for their manned flights, little would they have imagined how 'drones' would take-flight across the world as a disruptive technology. Various experiments and developments in the $19^{\text {th }}$ and $20^{\text {th }}$ centuries led to the proliferation of drones in several militaries. The first use of the term 'drone' was by the US Navy, back in 1935 where they commenced a program to produce a remotely-controlled target aircraft. ${ }^{1}$ Over the years, they came to be used increasingly for military activities. The use of drones in the Iraq War (2003-2011) made it notorious as a modern war machine, the use of which is still a subject of several debates.

In general, a pilotless aircraft, regardless of its function and specification is referred to informally as drone ${ }^{2}$ or formally as an unmanned aerial vehicle (UAV). Other terms such as, Remotely Piloted Aircraft (RPA), Remotely Piloted Vehicle (RPV), and Remotely Operated Aircraft (ROA) are common terminologies used in Europe. ${ }^{3}$ Unmanned Aircraft System (UAS) is another popular term, referring to a system weighing between 1 to 1,500 kilogram. ${ }^{4}$ The pilot could be sitting some meters or even hundred kilometers away which depends on each drone technology.

The turn of the $21^{\text {st }}$ century saw a significant change in the use of drone technology. Creative and informative thinking has now led to the proliferation of drone technology in the civilian sphere. Several industries are to benefit from the use of drone technology. Already, this new-age aircraft has been put to wide use from anti-terrorism operations to pollination, 3D-mapping to aerial photography, package delivery to environmental conservation, emergency response to law enforcement, and more, beyond their initial use as a recreational personal aircraft. Several Asian countries have taken cognizance of the potential of this technology in driving their national interests, benefitting various industries, from agriculture to surveillance. Civilian drone technology is in the stage of infancy. This is just the beginning of an era, whose future can be compared to the way mobile phones permeate our everyday lives.

Just as any other disruptive technology like the internet or 3D-printing, civilian drone usage poses a challenge not only to economic structures but also to law. Asian countries are currently home to several big manufacturers of civilian drones in the world. ${ }^{5}$ Inherently, the prospect of opportunities in commercializing and commodifying this technology makes these countries a fertile ground for numerous start-ups. These private entities and individuals either take advantage of the lax or no regulation scenario or are severely hindered by them.

Some developing countries in Asia are aware of drones' utilization for their

1 Roger Clarke, "Understanding the Drone Epidemic," https://www.parliament.nsw.gov.au/prod/ parlment/committee.nsf/0/f618f4da91a21907ca257c86001a331b/\$FILE/Article\%20-\%20Understanding\%20the\%20Drone\%20Epidemic.pdf, accessed on 23 January 2016.

${ }^{2}$ For the purpose of this paper, the more commonly used term in Asia is used despite its informality.

${ }^{3}$ Clarke, loc.cit.

${ }^{4}$ Lydia de Beer, Unmanned Aircraft Systems (Drones) and Law (Nijmegen: Wolf Legal Publishers, 2011), p. 2.

${ }^{5}$ RnR Market Research on 2015 announcement that SZ DJI, China was the leader in the manufacture of civilian drones. "Commercial Drones: Highways in the Sky, Unmanned Aerial Systems (UAS), Market Shares, Strategies, and Forecasts, Worldwide, 2015 to 2021," http://www.rnrmarketresearch.com/commercialdrones-highways-in-the-sky-unmanned-aerial-systems-uas-market-shares-strategies-and-forecastsworldwide-2015-to-2021-market-report.html, accessed on 21 February 2016. 
national interests. Indonesia, Thailand, and India have unique geographic conditions and national issues that can find great utility in civilian drones. However, to realize its fullest potential, a clear and robust legal framework for civil and commercial use of drones should be set first. This article provides an overview of the current legal situation in these three Asian countries, and lays stress on the urgency for having a national or even regional legal framework exclusive to drones.

\section{Current Legal Framework on Drone}

\section{A. Indonesia}

Drone use has mushroomed in Indonesia, keeping up with worldwide trends. Indonesia is one of the countries, where military UAV usage does not have a long precedence over civilian usage. ${ }^{6}$ Civilian drones are easily available for purchase all over the country. Drone sellers also have online presence catering to drone enthusiasts in the archipelago. Since 2013, the government and the public have successfully used drone technology in several programs. Some of the examples are listed below: ${ }^{7}$

Table 1: Use of Drones in Indonesia

\section{Government Programs}

Indonesia's Wulung drones (surveillance type) are used by various Ministries to monitor illegal logging and illegal fishing, active volcanoes, and forest fires since 2013.

The Indonesian tax office uses drones to track and survey palm-oil plantations and miners who misrepresent the actual size of their plantations and mines. ${ }^{1}$

The Indonesian National Police uses drones for traffic monitoring in Jakarta during the month of Ramadhan and Eid.

\section{Civilian Programs}

A group of researchers in Sumatera have been using drones to monitor the habitats of orangutans. This project identified the potential of drone usage in conservation, thereby pioneering a new class of drones, namely, Conservation Drones.

The Indonesian Center for Research and Technology (BPPT) uses quadcopters for monitoring Mount Sinabung, an active volcano in the North Sumatera.

The Dayak Tribe has used drones to gather proof against illegal palm oil companies, through visual data, tracking the stages of deforestation in striking before and after shots of the tribe's territory.

As an answer to the rapid growth in utilization of drones, in 2015, the Ministry of Transportation brought out the Indonesian Ministerial Regulation No. $90^{8}$ (hereinafter

${ }^{6}$ Kate Lamb, “Indonesia Readies Mass Production of Drones, Voice of America,” http://www.voanews. com/content/indonesia-readies-mass-production-of-drones/1651633.html, accessed on 20 February 2016.

7 Center for the Study of the Drone, "Drones in Southeast Asia," http://dronecenter.bard.edu/dronesin-southeast-asia/, accessed on 1 February 2016.

8 Indonesia, Peraturan Menteri Perhubungan tentang Pengendalian Pengoperasian Pesawat Udara Tanpa Awak di Ruang Udara yang Dilayani Indonesia (Minister of Transportation Regulation regarding Unmanned Aerial Vehicle within the Indonesian Air Space), Permenhub No. 90 Tahun 2015, BNRI No. 723 Year 2015 (Minister Regulation No. 90 of 2015, SG No. 723 Year 2015). 
referred to as the "Indonesian Regulation No. 90"). This may also be a calculated effort on the part of the Indonesian Government to enhance its international standing in the field of civil aviation by developing a legal environment that not only accommodates but also catches up with new technology in aviation. The ultimate purpose is to ensure and improve the Indonesian aviation safety level, which has been questioned by the world following various aircraft incidents in this country for the past years.

The Indonesian Regulation No. 90 is a rudimentary framework whose main provisions deal with the prohibition on flying drones within prohibited and restricted area, including airports, altitude limitations, and the administrative procedure to obtain flight permits before each flight. No classification is made to distinguish the applicants based on type, size, or function, thus leaving all categories of users to deal with the same administrative requirements and obtaining the same documents. The Indonesian Minister Regulation No. 90 prescribes mandatory insurance for permits.

Even though the Indonesian Aviation $\mathrm{Law}^{9}$ of which the Indonesian Regulation No. 90 is a part, is relatively recent, its drafters did not envisage the future development and integration of drones into the existing aviation infrastructure. This leads to a debate on whether the parent law could comply with recent developments and increasing use of drones. ${ }^{10}$ Political will is lacking to facilitate the much needed amendment to the Indonesian Aviation Law, leaving a framework for drones, still, in the level of Minister of Transportation regulations.

The Indonesian Regulation No. 90 is silent when it comes to penalties, leaving any interpretation as regards penalizing drone-related crime to existing Indonesian law, particularly the Indonesian Aviation Law. This situation may lead to misinterpretation of the law or even abuse the law using loopholes. Fortunately, so far, no serious case has been registered in relation to drones, yet, in Indonesia.

\section{B. India}

It is uncommon for an incident, such as a pizza delivery, to kick start a debate in the legal circles. However in May 2014, when a popular pizzeria decided to avoid the notorious Mumbai traffic, and used a drone to deliver a pizza pie, the question of legality in the use of civilian drones was put out in the open. ${ }^{11}$ A police enquiry into this incident had limited forward movement, as without laws, there could be no violation and hence no complaint, formal arrest, and/or seizure.

A few months later it was widely reported that Amazon would run pilot drone deliveries in Bangalore and Mumbai cities. ${ }^{12}$ Shortly after this announcement, in

${ }^{9}$ Indonesia, Undang-Undang tentang Penerbangan (Law regarding Aviation), UU No. 1 Tahun 2009, LN No. 1 Year 2009 (Law No. 1 of 2009, SG. No. 1 of 2009).

10 Ridha Aditya Nugraha, "Fenomena Drone: Tantangan Baru bagi Hukum Udara Indonesia," [Drone Phenomenons: New Challenges for Indonesia's Air Law], http://www.hukumonline.com/berita/baca/ lt569601b5795dc/fenomena-drone--tantangan-baru-bagi-hukum-udara-indonesia-broleh--ridha-adityanugraha- accessed on 26 January 2016.

${ }^{11}$ Rashmi Rajput, “Mumbai Police Seeks Explanation on Drone Pizza Delivery,” http://www.thehindu. $\mathrm{com} /$ news/cities/mumbai/mumbai-police-seeks-explanation-on-drone-pizza-delivery/article6043644. ece, accessed on 8 February 2016.

12 Krithika Krishnamurthy, "India to be Launch Pad for Amazon's Plan to Deliver Packages Using Drones; Deliveries May Start by Diwali," http://articles.economictimes.indiatimes.com/2014-08-20/ news/53028827 1 prime-air-drones-outdoors-amazon, accessed on 8 February 2016. 
October, the Directorate General of Civil Aviation (DGCA), issued a public notice ${ }^{13}$ to the effect that 'no non-government agency, organization, or an individual will launch a UAS in Indian Civil Airspace for any purpose whatsoever' ${ }^{14}$ until the DGCA adopted regulations for its certification and operation. On $21^{\text {st }}$ April 2016, the DGCA came out with a 'Draft' document on Guidelines for obtaining Unique Identification Number (UIN) \& Operation of Civil Unmanned Aircraft System (UAS), ${ }^{15}$ for which the DGCA sought to receive public comments and remarks, within a month.

Even before the DGCA notice and subsequent draft guidelines, drones had infiltrated Indian markets, been put to use in various fields, and now, many more applications are being considered by entrepreneurs, engineers, and policy makers, alike. The Delhi Police, use them for riot surveillance, ${ }^{16}$ street patrol etc.; ${ }^{17}$ the Indian National Disaster Management Authority use them to survey flood-affected areas in order to take timely responsive actions; ${ }^{18}$ a national tiger reserve ${ }^{19}$ has expressed interest to use drones to curtail poaching; and prototype air ambulances are being evaluated to render rural medical care and support organ donation..$^{20}$ Apart from this, several media and cinema houses are using drones as a new tool for photography. There is a rise in the number of companies that offer such aerial photography services. These are only a few examples of the extent to which drones are being used for civilian purposes, proving that it is no more an expensive toy in the hands of a few.

While so, one might wonder about the effect of the DGCA ban on such activities. The ban, although a singular statement, does provide an interim solution. Drones can be used, subject to approvals 'from the Air Navigation Service provider, the Defense, Ministry of Home Affairs, and other concerned security agencies, besides the DGCA. ${ }^{21}$ However, this can prove to be a time consuming and expensive task. For example, a popular aerial photography company in New Delhi, Quidich, shifts the burden of obtaining permissions to the person seeking services. It would seem ludicrous for a couple to obtain these permissions to shoot their wedding, whereas the same might seem worthwhile for a media network seeking to cover elections. Such unfair terms can be attributed to the knee-jerk reaction found in the DGCA notice, which does not classify the permission to be sought on the basis of a functional scale.

Looking ahead, the DGCA has, for a basis, a loose structure, from which it can work

13 Directorate General of Civil Aviation of India, Public Notice No. 05-13/2014-AED, dated 7 October 2014.

${ }^{14}$ Ibid.

15 Office of the Director-General of Civil Aviation, India, http://dgca.nic.in/misc/draft\%20circular/ AT Circular\%20-\%20Civil UAS(Draft\%20April\%202016).pdf, accessed on 6 June 2016.

${ }^{16}$ Abhishek Angad and Sarah Hafeez, "Police Use Drones to Find Bricks, Bottles," http://indianexpress. com/article/cities/delhi/police-use-drones-to-find-bricks-bottles/, accessed on 8 February 2016.

17 “Delhi Police to Use Drones for Street Surveillance," http://www.livemint.com/Politics/judPhYHQsNw3T5p6iQgllN/Delhi-Police-to-use-drones-for-street-surveillance.html, accessed on 8 February 2016.

18 "Unmanned Aerial Vehicle in Kedarnath to Help Rescue, Relief Operation: NDMA," http://articles. economictimes.indiatimes.com/2013-07-08/news/40443533 1 uav-unmanned-aerial-vehicle-kedarnath, accessed on 8 February 2016.

19 Vishal Sharma, "Jharkhand's Tiger Reserve to Use Drones for Surveillance," http://www.hindustantimes.com/india/iharkhand-s-tiger-reserve-to-use-drones-for-surveillance/story-TfxduW3x546TzuUkr8dezJ.html, accessed on 8 February 2016.

20 Jessica Wapner, "Medical Transport Drones Could Transform Healthcare in Overcrowded Cities," http://europe.newsweek.com/india-organ-transplant-drones-419013?rm=eu, accessed on 8 February 2016.

${ }^{21}$ Directorate General of Civil Aviation of India, Public Notice No. 05-13/2014-AED, dated 7 October 2014. 
towards making a strong law. As early as 2007, the Centre for Military Airworthiness and Certification (CEMILAC) had recommended for an airworthiness clearance for all drones. ${ }^{22}$ Later in 2009 and in 2011, the Aeronautical Development Establishment organized International Conferences on Autonomous Unmanned Vehicles (ICAUV), the only government-organized exclusive events on drones. Later in October 2014, following the earlier mentioned DGCA notice and an announcement that regulations would be adopted soon, the Consortium of Unmanned Vehicular Systems in India, an industry lobby, submitted a detailed proposal in the form of an advisory. ${ }^{23}$ It contained methods to manage standards, for certification of operators, and also suggested measures on licensing, insurance, and safety. The interests, and availability of knowledge from many stakeholders, their queries to authorities etc., ought to have persuaded the DGCA to take a holistic approach while formulating regulations.

On the contrary, the 2016 Draft Guidelines briefly provide a classification of drones on the basis of weight and then provide that to fly drones above 200 feet, first one must apply to the DGCA for the Unmanned Aircraft Operators Permit, at least ninety days prior to the flight date and further seek an additional permission from the Ministry of Home Affairs, the Airport Authority of India, the local police and every owner of a property over which flight takes place. This is a highly bureaucratic procedure that would consume about four until six months per event. The process to obtain a Unique Identification Number, while elaborate in seeking certificates for an operator's antecedents, permissions for all frequencies used etc, is also quite tedious for an operator. The guidelines also make insurance for third-party liability a mandatory requirement. The most criticized provision, however, relates to the drone operator's certification, which is almost equivalent to a certification expected from a pilot. This will definitely act as a hurdle in realizing the full potential of civilian drone use, as a considerable amount of investment will have to be made by each operator to obtain the required certification.

The civilian drone industry in India is booming, hoping for a favourable legislation, by making use of some of the uncertainties in laws for now. They have their fair share of obstacles too. When the Government of India opened defense manufacturing to private sector, a list of objects that require compulsory licenses was issued. Recently, the Department of Industry Policy \& Promotion (DIPP), Ministry of Commerce and Industry updated the list to include 'UAVs, Remotely Piloted Vehicles (RPVs), autonomous programmable vehicles, unmanned lighter than air vehicles (including drones, balloons and UAVs),', ${ }^{24}$ also identifying that they could have dual use. Although the DGCA notice does not explicitly prohibit manufacturing or sale of drones, it appears that a joint reading with the DIPP Press Note would impose limitations.

Even as the nation waits for the DGCA to come up with a regulatory framework, States are resorting to interim measures. The Delhi Police is developing Standard Operating Procedures (SOPs) for drones, at the instance of the Ministry of Home Affairs, which may later be shared with the other states. ${ }^{25}$ Contemporarily, State

22 “UAV Regulations in India - A Pre - Requisite," http://www.usai.in/regulations.html, accessed on 8 February 2016.

23 Pranav Dixit, “Something in the Air: Drones Finally Making a Comeback to Indian Skies," http:// www.hindustantimes.com/tech/something-in-the-air-drones-finally-making-a-comeback-to-indianskies/story-Ka0UCL1nwB90NoRU4Nuw4M.html, accessed on 8 February 2016.

24 "List of Defence Items Requiring Industrial Licenses," http://dipp.nic.in/English/acts rules/Press Notes/pn3 2014.pdf, accessed on 22 February 2016.

${ }^{25}$ Alok Singh, “Delhi Police Work on SOP for Use of Drones,” http://indianexpress.com/article/cities/ delhi/delhi-police-work-on-sop-for-use-of-drones/, accessed on 8 February 2016. 
Governments are seeking to bring a truant drone within the ambit of existing law by terming it a 'public nuisance', 'endangering public safety', etc. For example, in the State of Tamil Nadu, on capturing an unauthorized drone and its operator, 'a police complaint was filed and a case was registered under Sections 287 (negligent conduct with respect to machinery) and 336 (endangering the life or personal safety of others), of the Indian Penal Code $e^{26}, 27$ which carry a punishment of imprisonment for up to six months, or with a fine up to INR 1,000 (approximately USD 15), or with both, and imprisonment for up to three months, or with fine up to INR 250 (approximately USD 4), or with both, respectively. The DGCA notice in itself does not mention any penalty for a violation.

Increasing pressure mounts day-by-day on the DGCA, from the drone industry and consumers, for an integrated and comprehensive response in the form of a new regulation. Such a response must be timely to cope with such a technological revolution.

\section{Thailand}

The first use of drones in Thailand was during the Rom Krauw War between Thailand and Laos in 1988, to patrol and take photos of the war areas. However, its efficiency was debatable due to the tropical geography and insufficient technology at that time. Influenced by the success of US drone operations in the Gulf War of 2003, Thailand began the local development of drones in 2004, through the Drone Research and Development Project.

In recent times, Thai educational institutions and private entities are also investing in drone development projects for several purposes, such as entertainment, media production, security, etc. Taking notice of the rapid usage of civilian drones, the Department of Transportation of Thailand, on 27 August 2015, brought forth the Announcement of Department of Transportation of Thailand on Drone ${ }^{28}$ (hereinafter the "Thai Drone Announcement"). This was issued in accordance with Section 24 of Thai Air Navigation Act, $1954^{29}$ (hereinafter the "Thai Navigation Act"), as a supplementary law.

Section 24 of the Thai Navigation Act reads as follows:

"No person shall control or release a pilotless Aircraft or release a Parachute unless written permission has been obtained from the Minister and the conditions specified by the Minister are complied with."

Section 24 of the Thai Navigation Act grants the Minister of Transportation authority and discretion to permit and specify the conditions of the controlling and releasing a drone or parachute. The Thai Drone Announcement provides conditions for grant of permit. However, this new law has raised several issues as regards its application. There is no clarity whether the Thai Drone Announcement is to be read with the other provisions of the parent Act, such as registration, flying routes, and places of takeoff and landing. For that, it is important to define whether a drone falls

${ }^{26}$ India, Penal Code, Act No. 45 (1860).

27 “Permission Needed to Fly Drone in Public," http://www.thehindu.com/news/cities/chennai/permission-needed-to-fly-drone-in-public/article6764693.ece, accessed on 8 February 2016.

${ }_{28}$ Thailand, Announcement of Department of Transportation of Thailand on the Provisions and Conditions on Commanding and Releasing Pilotless Aircraft, B.E. 2558 (2015).

${ }^{29}$ Thailand, Air Navigation Act, B.E. 2497 (1954). 
within the meaning of "aircraft" under the Thai Navigation Act. Under the latter, 'aircraft' means all machines that derive support in the atmosphere from the reaction of the air except for objects which are exempted under the Ministerial Regulations. In 2005, the Department of Transportation Regulation ${ }^{30}$ (hereinafter the "Thai DOT Regulation of 2005") was issued specifying the objects which are not defined as aircraft under the Thai Navigation Act. Section 2 of the Thai DOT Regulation of 2005 states that "small aircraft used as toy" is not an aircraft under the Thai Navigation Act. However, it does not cover helicopters, multirotors or multicopters, while most of the drones in use are multicopters. Inherently, there is conflict and ambiguity.

The Drone Announcement contains fundamental provisions for flying and release of drones, such as conditions to grant permission for drones in different categories; registration; prohibitions to fly in prohibited Area, restricted area and danger area; safety rules; limitations on attitude; prohibited conditions; and the authority of the Minister and the Permanent Secretary of the Ministry of Transportation in case the operation of drones does not comply with the above said provisions. The permission to be granted is divided into three tiers: ${ }^{31}$

\begin{tabular}{ll}
\hline \multicolumn{1}{c}{ Permission } & \multicolumn{1}{c}{ Specification } \\
\hline Written permission for general public & $\begin{array}{l}\text { Hobby, entertainment, or sport drones with weight } \\
\text { not exceeding 2 kg }\end{array}$ \\
\hline Registered permission & $\begin{array}{l}\text { Hobby, entertainment, and sport with weight } \\
\text { between 2 } \mathrm{kg} \text { and } 25 \mathrm{~kg} ; \text { or others, e.g. news } \\
\text { reporting, photography, movie production, and } \\
\text { research drones with weight not exceeding 25 kg }\end{array}$ \\
\hline Specific case-by-case permission & Any kind of drones with weight over 25 kg \\
\hline
\end{tabular}

However, the Thai Drone Announcement does not contain any sanction or penalty in case the provisions are breached. It only mentions that if a user of drone does not comply with the provisions, the control or release of drone will be restrained. The lack of sanction and penalty in the Thai Drone Announcement might reflect on the intention of the drafters to automatically apply the penal provisions of the Thai Navigation Act. If that is the case, as an example, a drone manufacturer which does not have a valid license for aircraft (drone) manufacturing issued by the Director-General of Department of Civil Aviation (DCA) ${ }^{32}$, to imprisonment for a term not exceeding five years and/or a fine not exceeding one million Thai Baht (approximately USD $28,000) .^{33}$ The only one penalty under the Thai Navigation Act that directly relates to the Drone commanding and releasing comes under section 78(1), which states that any person who is commanding or releasing a pilotless aircraft without obtaining written permission from the Minister shall be liable to imprisonment for a term not exceeding one year or a fine not exceeding forty thousand Thai Baht (approximately

${ }^{30}$ Thailand, Department of Transportation Regulation on non-Aircraft Object, B.E. 2548 (2005).

31 Thai Drone Announcement, see sections 5, 6, 10, and 18.

32 Recently, the Thai Department of Civil Aviation (DCA) has replaced the Civil Aviation Authority of Thailand (CAAT) on 1 January 2016. The CAAT assumed control of the department's functions, including airspace oversight, infrastructure development, the promotion and development of Thailand's aviation industry, as well as negotiating air services agreements with international civil aviation organisations.

${ }^{33}$ Thai Navigation Act, see section 89. 
USD 1,100) or both. While so, without an explicit mention of a penalty, much is left to the interpretation of law enforcement agencies and lawyers.

As mentioned before, most of the drones which are multicopters fall within the definition of aircraft under the Thai Navigation Act. The Thai Navigation Act primarily deals with traditional aircrafts and not the variants of drones that are being sold in markets now. The Thai Drone Announcement seems inadequate and will certainly face challenges in its application. However, considering that this was drafted as a quick response to civilian drone proliferation, the Department of Transportation may have chosen to issue an Announcement as it is easier to revise and amend than an Act or Regulation.

\section{Urgency for National and Regional Legal Framework}

\section{A. Comparison between Indonesia, India, and Thailand}

\section{Existing Laws and Effects}

In 2015, an incident with a drone occurred in Jakarta, when a drone fell into a building located in the city center before being handed to the police. Within the early days of the Indonesian Regulation No. 90, the drone operator was being processed under this regulation and turned out that there was no criminal intent or act. ${ }^{34}$ The drone operator did not know that the Indonesian Regulation No. 90 had been enacted. At the end, the drone operator was released after making a statement letter that he will abide by the new regulation. ${ }^{35}$ The enforcement was lenient as it sought to familiarize the society with the new regulation. In general, no significant issues have arisen with drone usage or its regulation, yet, in Indonesia. Despite its 'simplicity', appreciation must be still addressed to the Indonesian government since it means there is 'still' an effort to keep the legal framework up-to-date. ${ }^{36}$ However, clarification and detailed explanation relating to mandatory insurance, operator certification, etc, should be given at the earliest.

India has a different scenario, wherein its DGCA has reacted to civilian drone usage with a public notice having the effect of general ban on its operation and prescribing generally that approvals be sought from several government authorities, if necessary. ${ }^{37}$ In India, although the promise of a comprehensive framework for civilian drone usage and its regulation hangs, such an interim measure has raised several questions ranging from classification of drones for approvals, use by State authorities, personal use, etc., to how a contravention of the Indian DGCA public notice is to be dealt with and penalized. In effect, this means that the same interim measure of seeking approvals is applicable to a person shooting a family photograph in his lawn, a farmer surveying his land, cargo delivery companies, and a news network that is covering a public meeting, placing the same burden of approval on users, who are in

34 Septiana Ledysia, "Polisi: Jika Ada Pelanggaran, OX Pemilik Drone Bisa Dipidana," [Police: If there is any offence, drone's owner can be criminally charged], http://news.detik.com/berita/2983492/polisijika-ada-pelanggaran-ox-pemilik-drone-bisa-dipidana, accessed on 19 February 2016.

35 Mei Amelia R, "Kembalikan Drone yang Jatuh di Menara BCA, Polisi: Sementara Rekaman Disita," [Returning drone that fell in BCA Tower, Police: Records will be confiscated temporary] http://news.detik. com/berita/2985250/kembalikan-drone-yang-jatuh-di-menara-bca-polisi-sementara-rekaman-disita, accessed on 19 February 2016.

${ }^{36}$ Ridha Aditya Nugraha, loc.cit.

37 Directorate General of Civil Aviation of India, Public Notice No. 05-13/2014-AED, dated 7 October 2014. 
unequal situations. Consequently, the Indian DGCA public notice limits or puts to halt most activities that can utilize drone technology.

Similarly, in Thailand, the Drone Announcement was the answer to civilian drone usage. This announcement is not without criticism. Just as in Indonesia, questions abound on exact boundaries of prohibited, restricted, or danger area when no sufficient details are provided. Permission requirement provisions ${ }^{38}$ for operating hobby, entertainment or sport drone within the Drone Announcement could become a potential obstacle for technology and industry development. Just as in India, the burden is on drone operators to seek permits. Further, the operation of the drone that weighs over $2 \mathrm{~kg}$ but not exceeding $25 \mathrm{~kg}$ for hobby, entertainment or sport must have a valid insurance covering damage to body, life and properties of third parties not less than one million Thai Baht (approximately USD 28,000) per time. Insurance would eventually cost more than the drone itself. This provision makes the operation of drones very expensive.

\section{Penalties}

Even as the countries grapple with the idea of regulation of drones, it seems more urgent to devise penalties for truant users. In India, despite the lack of a penal provision in the DGCA notice, the police authorities have resorted to using the Indian Penal Code to file cases against such truancy. There is the possibility under the Indian Penal Code to read criminal laws together to impose a penalty. ${ }^{39}$ The use of the Indian Penal Code is adequate for any crime or violation committed in the use of civilian drones. This could be a sound reason why the DGCA did not mention any penalty for contravention of its notice. For example, one only needs to check what sort of actions, that draw penalties, are committed or omitted along with 'negligent conduct with machinery'; 40 this could be nuisance, causing grievous harm, etc,.

Meanwhile in Thailand, the Thai Drone Announcement does not contain any penalty provision. If a drone operation does not obtain permission from the Minister of Transportation, the person(s) operating drone shall be subject to penalty provisions under the Thai Navigation Act. Furthermore, any damage caused from drone operation is also subject to other Thai laws, such as Thai Criminal Code, Civil Code and Commercial Code, Intellectual Property Act, and Privacy Act.

The Indonesian situation has similarities with Thailand. There is no sanction within the Indonesian Regulation No. 90. Thus, the Indonesian Aviation Law shall bear this issue together with any other relevant Indonesian laws, such as the Indonesian Copyright Law and the Indonesian Telecommunications Law. Under the Indonesian Aviation Law, a maximum two-year imprisonment and a fine up to five hundred million Rupiah (approximately USD 37,200) are imposed on drone operators who endanger aviation safety and people on ground. ${ }^{41}$ Originally this provision is intended for aircraft pilots and not drone operators. It is an issue, like in Thailand, that must be resolved immediately.

\footnotetext{
38 Thai Drone Announcement, article 5(1)(b).

39 "Permission Needed to Fly Drone in Public," http://www.thehindu.com/news/cities/chennai/permission-needed-to-fly-drone-in-public/article6764693.ece, accessed on 8 February 2016.

${ }^{40}$ Ibid.

41 The Indonesian Aviation Law, Art. 411.
} 


\section{The Way Forward}

Considering the geography and political structure of India, and the economic potential for civilian drone usage, it would be best to have a separate legal and regulatory framework for drones. Such a framework needs to address the various requirements of stakeholders, from classification of drones, certifications, operation procedures, approvals, qualification of drone pilots, standards for safety, insurance, etc,. The Indian DGCA may also considering installing a specialized department for drones, under its control, in order to have efficiency in regulation.

As for Thailand, its government may have to revise both Thai Navigation Act and the Drone Announcement to define aircraft and their categories. The purpose is to distinguish drone from large aircraft; thus, the former is not subject to the same provisions as aircraft, so that there is be more room to expand drones' function. Since revising Thai Navigation Act is a long process, the easiest way would be to replace the current Ministry of Transport Regulation on non-Aircraft Objects ${ }^{42}$ in order to exclude drones from being defined as aircraft for the purpose of the above-mentioned Act. Further, relevant authorities need to be advised on the procedures concerning issuance of licenses as until now there are neither clear instructions for prospective applicants to follow, nor any internal policies or guidelines governing the procedure involved in examining the applications. It is hoped that clear guidelines, detailing relevant procedures, setting time frames and unambiguous definitions etc, will be brought forth in the near future.

In comparison with these two countries, the fact that Indonesia has detailed some aspects of drone usage in its Regulation places it on a better position for now. Just as in Thailand, Indonesia must also begin by defining drone distinguishing it from large aircraft. Further, penal provisions under the Indonesian Aviation Law 2009, should be applied differently to drones. Otherwise, they would intimidate the growing civilian drone industry. To keep up with the growth of drone usage, personnel within the Indonesian DGCA must be trained to handle applications for permits and knowledge about administrative and penal procedures must be disseminated to them.

\section{B. Homework for the Governments}

Disruptive technologies have posed challenges for the law, confronting regulators with the need to balance justice and an appreciation of new realities with powerful interests and existing paradigms. ${ }^{43}$ Addressing the issue of disruptive technologies, Professor Katyal remarks "The tech community's solipsistic focus on disruption, to the exclusion of human and legal values, can be problematic." 44 There is a need for special rules to deal with a new technology in order to regulate new forms of conduct, relationships, resolve conflict of laws and update laws. The Governments must take prompt response to the disruption caused by drones to nurture the technology, make

${ }^{42}$ Section 2 of the Ministry of Transport Regulation on non-Aircraft Objects has excluded small aircraft used as toy from definition of "aircraft" under the Thai Air Navigation Act, B.E. 2497 (1954). However, it does not exclude helicopter or multi-rotor aircraft used as toy from the definition of "aircraft" under the Act.

${ }^{43}$ Angela Daly and Steve Collins, "Disruption and the Law," http://peerproduction.net/issues/issue-6disruption-and-the-law/, accessed on 20 February 2016.

${ }^{44}$ Oral remarks that introduced the Symposium on 8 November 2013. Neal Katyal, "Disruptive Technologies and the Law," Tbe Georgetown Law Journal Vol. 102 Issue 6 (2014): 1685, accessed on 20 February 2016, http://georgetownlawjournal.org/files/2014/08/Katyal-Disruptive.pdf. 
available its benefits to general public and at the same time to protect against the vices of this technology.

\section{Safety and Security}

Drones are similar and at the same time different from traditional aircrafts. The laws, procedures and standards applied to aircrafts cannot be automatically extended to drones. For example, requiring a flight plan from all drone operators is imprudent. A clear understanding of the subject matter is a necessary pre-requisite to adopting safety and security standards. Some of the essential points for consideration are as follows:

Clear definition of drone; classification based on type, size and function; standards for components used, for example, several accidents have been caused by weak collision avoidance mechanisms, ${ }^{45}$ clearly such 'accidents give rise to ample cause for concern about the potential for harm to people and property, and highlight the need for an assessment of the adequacy of existing regulatory frameworks for public safety'46; nature of payloads that can be fitted to or transported on a drone; establish certification requirements for the system, operators and controllers; define communication standards, and develop a uniform air traffic control and regulation network, explore the possibility of creating air corridors for drones; define boundaries for usage clearly identifying and publicizing no-fly zones, and also require that 'GeoFences' be programmed to keep certain critical infrastructure or airspaces off limits ${ }^{47}$; train personnel to handle contingencies if any in the usage of drones, including the capturing of truant drones, for example the Dutch Police have been training eagle to snatch 'dangerous' drones in public since 2016, ${ }^{48}$ amongst other things.

Drones can be compared to flying computers and just as any other computer, they are prone to cyber-attacks, which include but are not limited to hacking, jamming ${ }^{49}$, and spoofing ${ }^{50}$. As they are heavily dependent on digital components and communication, with little human interference, the vulnerability of drones is likely to jeopardize safety, security, and efficiency of their operation. Cyber security and related laws are still in a nascent stage at both international ${ }^{51}$ and national levels.

45 "Drohne "Luna": Bundeswehr verheimlichte Beinahe-Crash mit Airbus," http:// www.spiegel.de/ politik/deutschland/drohne-luna-bundeswehr-verheimlicht-beinahe-crash-mit-airbus-a-903337.html, accessed on 20 February 2016.

${ }^{46}$ Roger Clarke, "Understanding the Drone Epidemic," Computer Law \& Security Review 30 (2014): 244, accessed on 20 February 2016, doi: http://dx.doi.org/10.1016/j.clsr.2014.03.002.

47 The Phantom series of drones, manufactured by DJI, are programmed with the co-ordinates of thousands of airports around the world. It cannot enter these areas. If it tries, it will be forced to land; and within a two kilometer radius of a major airport its height will be capped at just $10 \mathrm{~m}$.

48 Toby Sterling, "Dutch Police Train Eagles to Snatch Enemy Drones," http://www.reuters.com/article/us-dutch-police-drones-idUSKCNOVB136, accessed on 11 February 2016.

49 Álvaro Herrero et al., International Joint Conference SOCO'13-CISIS'13-ICEUTE'13, Salamanca, Spain, September 11th-13th, 2013 Proceedings, (Basel, Springer International Publishing, 2014), p. 411.

50 Faking the sending address of a transmission to gain illegal unauthorized entry into a secure system. "Explore Terms: A Glossary of Common Cybersecurity Terminology," https://niccs.us-cert.gov/ glossary\#Spoofing, accessed on 20 February 2016.

51 Chapter 4 of Annex 17, Chicago Convention, prescribing States to take measures against cyber threats; United Nations Manual on the Prevention and Control of Computer Related Crime, International Review of Criminal Policy nos. 43 and 44 (1999); United Nations Resolution on Combating the Criminal Misuse of Information Technologies GA RES 55/63, UNGA 55th Session, 81st Plenary Meeting UN Doc. A/ RES/55/63 (2001); 2001 Cybercrime Convention, European Treaty Series no. 185 or the Budapest Conven- 
While so, the situation demands that before drones proliferate into everyday use, cyber security issues need to be resolved by assessing the 'spectrum of threats, not simply the worst one imaginable, in order to properly understand and coherently deal with the risks to people, institutions, and the economy. ${ }^{52}$

A hybrid system merging elements of the aviation and IT industry must be developed to create a conducive environment for safe and secure operation. Adopting a prescriptive approach, as suggested by Stefan Kaiser ${ }^{53}$, airworthiness standards must be applied to drones for their reliable and stable use. Not prescribing such a standard fearing an adverse economy would have dangerous consequences as "...the quality standards commonly practised in the information technology industry do not suffice airworthiness standards". ${ }^{54}$ The manufacturers must consider this a responsibility rather than a burden. The risk of using Commercial Off The Shelf Components or COTS would be greatly reduced if standards are set. However, the question of economy in manufacturing will remain, making the availability of inexpensive drones not so common.

A conflict arises in imposing safety and security standards on drone usage; the liberty to use what one owns versus restrictive control. All stakeholders must participate and take efforts to build public confidence in the use of drone technology. Moreover, it should be kept in mind that unwarranted restrictions are not imposed. For example, in Thailand, using drones for journalism is restricted to registered media entities and not for the public. Such a restriction would infringe on journalistic freedom, where the drone is simple a tool for gather news.

\section{Privacy}

Drones, by nature can be invasive, raising the essential question of the right to privacy. Recently, in Thailand, the police and military were allowed to use any procedure, including using drones, to inspect activities of people in order to maintain security and peace in the country. When and where does this activity become intrusive and unlawful? L. Lessig states in his first cyberspace book, Code, that "a difference in degree can become a difference in kind with enough technology".55

None of the countries in this study has a strong and independent privacy or data protection law that can constitute a protective legal framework for its citizens. For example, in India, the Constitution ${ }^{56}$ in Article 21 grants the freedom of life and liberty. Judicial interpretation, over the years, has recognized the right to privacy as a fundamental freedom under Article 21. However, it is hard to say if such recognition can be applied generally to drone-related activities as well.

While so, a violation of privacy means that the victim will have to take recourse to

tion of the Council of Europe was opened for signature in November 2001 and came into force on 1 July 2004. As of October 2014,44 states have ratified the convention, while a further nine states had signed the convention but not ratified it.

${ }^{52}$ John Mueller and Mark G. Stewart, Terror, Security, and Money: Balancing the Risks, Benefits, and Costs of Homeland Security (Oxford: Oxford University Press, 2011), p..16.

53 "RPAS/UAS: A Challenge for International, European, and National Air Law," Workshop of EASA and Institute of Air and Space Law held at University of Cologne, 23-24 May 2013.

${ }^{54}$ Stefan A. Kaiser, "UAVs and Their Integration into non-Segregated Airspace," Air and Space Law Vol. 36 Issue 2 (2011): 161-172.

${ }^{55}$ Lawrence Lessig, Code and Other Laws of Cyberspace (New York: Basic Books, 1999), p. 21.

${ }^{56}$ India, Constitution of India (1949). 
national civil or tort laws. 'Whilst some existing tortious laws, such as on trespassing, might prohibit [drones] from entering private property, their ability to exclude unwelcome surveillance from outside the property is limited.... This leaves individuals with little in the way of actionable rights against [drones] that are used to survey their private property. ... [Drone] technology thus renders the traditional commonlaw assumption -- that privacy can be protected by the individual -- a fallacy. ${ }^{57}$

However, all three countries have adopted or are a party to other international declarations and conventions such as the Universal Declaration of Human Rights ${ }^{58}$ and the International Covenant on Civil and Political Rights, which recognise the right to privacy ${ }^{59}$ The rise of drone usage is a sufficient reason for these nations to work on laws, if there aren't any yet, towards protecting a person's right to privacy.

\section{Insurance and Liability}

A strong legal and regulatory framework must contain within itself a strong liability framework too. An accident caused by drones will give rise to liability for damage to persons or property. Damage on ground, collisions, cyber attacks, violation of human rights including the right to privacy, tortious acts etc., are the possible scenarios that may give rise to liability. This then leads to questions on the applicable law, identification of the liable party, limit on liability, and so on. In general, the existing aviation law concerns civil and criminal cases in relation to manned aircraft. As cited above, in some instances, national laws, tort laws, or even cyber laws may be applied. The feature that is unique to drone liability is that they are an amalgamation of IT and aviation, which means the operator who is away from the launch or release area and the crash site may bring in a third jurisdiction thus giving rise to the issue of conflict of laws. The operators' duty and responsibility must be well identified in order to clearly identify liability. Further, the traditional principles of absolute liability, strict liability, and negligence must be deliberated in relation to drones before extending their application in assessing liability.

Indonesia and Thailand have a mandatory insurance requirement for flying permits. This is often costlier than the drone itself. Moreover, not many insurance companies have full knowledge over the coverage or even applicable premiums for civilian drone use. The last resort is using the existing standardized insurance policies. Some insurance companies go further in refusing to provide a policy for drone usage. Insurance is a non-negotiable requirement for safe operation of drones. However, drones and their usage must be analysed and broadly classified by the insurance industry as well, in order to provide adequate and appropriate insurance protection. The cover bought by a hobbyist flying a palm sized drone should certainly be different from that of an organization using larger drones for surveillance.

\section{National Registry}

A National Registry for drone would serve the purpose of identifying a drone with

57 Brendan Gogarty and Meredith Hagger, "The Laws of Man Over Vehicles Unmanned: The Legal Response to Robotic Revolution on Sea, Land and Air," Journal of Law, Information and Science Vol. 19 (2008): 73, accessed on 20 February 2016, http://www.jlisjournal.org/content/Gogarty\%20and\%20Hagger\%20 JLIS\%2019.pdf.

${ }^{58}$ United Nations, Universal Declaration of Human Rights, adopted on 10 December 1948.

${ }^{59}$ United Nations, International Covenant on Civil and Political Rights, adopted on 19 December 1966. 
its user. Joseph Lorenzo Hall, in his article 'License Plates' for Drones' ${ }^{60}$, advocates the use of radio-frequency drone identifier (RFDID) which would allow members of the public to itemize the drones in a given airspace with relatively simple radio receivers. Ideally, a specialized agency such as the DGCA or any department under it may maintain a drone registry. However, it should be taken into consideration that drones are also 'consumer goods' like a laptop or mobile phone. It is easily transferrable and destructible. In such a case, elaborate registration procedures or subsequent modifications in title would be problematic.

\section{Regional Cooperation: How Far at the Moment?}

\section{ASEAN Legal Framework on Drones: Another ASEAN Open Skies?}

Unlike the EU, ASEAN has consensus as its basis rather than integration. The binding nature of such consensus is also debatable. However, in the recent years, efforts have been made to cooperate on a superior scale, possibly moving towards integration on some levels. The ASEAN Open Skies ${ }^{61}$ is a lesson. A year after its coming into force, there were issues regarding cabotage enforcement when some States refused to open up secondary cities or capitals etc. ${ }^{62}$ Unfortunately, no penalties could be imposed to those States. Therefore, there is a possibility that any law or regulation issued at the ASEAN level would reach the same fate.

As the proliferation of drones is not uniform in Asia, it may be premature to establish an ASEAN Legal Framework on Drone. Further, the political situation in Asian countries is volatile to have uniform laws. For example, the military junta in Myanmar would see drones' function far different from that of the Indonesian democratic government. Combining ten member states' interests within a single ASEAN Legal Framework on Drone may be impractical, as reaching a consensus would not always be easy. Amending laws would then become a hassle, hampering growth with unnecessary administrative requirements.

However, all is not lost; the civilian drone industry is in its infancy and the challenges faced by all nations in their regulation are the same. What ASEAN can do now is to set up soft laws in the form of recommendation or guideline on drones. In this case, the most realistic way is if the soft laws contain safety provisions. There is no specialized ASEAN agency established to deal with aviation, like the European Aviation Safety Agency (EASA) in the EU. However, an initiative in the form of soft laws may lead to larger cooperation in future.

\footnotetext{
${ }^{60}$ Joseph Lorenzo Hall, “'License Plates' for Drones," https://cdt.org/blog/license-plates-for-drones/, accessed 20 February 2016.

${ }^{61}$ The ASEAN Open Skies Policy came into effect on 1 January 2015, despite three airline tragedies in 2014. This ASEAN Open Skies Policy, which is also known as the ASEAN Single Aviation Market, is intended to increase regional and domestic connectivity, integrate production networks and enhance regional trade by allowing airlines from ASEAN member states to fly freely throughout the region via the liberalization of air services under a single and unified air transportation market. See "ASEAN Open Skies Policy to be Implemented in 2015," http://www.aseanbriefing.com/news/2015/01/02/asean-open-skies-policy-implemented-2015.html, accessed on 12 February 2016.

${ }^{62}$ Paige Lee Pei Qi and Rosa Ocampo, “ASEAN Open Skies Impeded by Limited Landing Slots," http:// www.ttgasia.com/article.php?article id=26522, accessed on 10 February 2016.
} 


\section{Should India Engage in Regional Cooperation?}

The International Civil Aviation Organization's (ICA0) Remotely Piloted Aircraft Systems Panel (RPASP) 'aims to deliver proposed SARPs for unmanned aircraft to the ICAO Council for its consideration beginning in $2018 .^{63}$ Meanwhile, the Indian DGCA has been in the process of developing a legal framework for drones since 2014, and one cannot brush away the thought that India seems to be waiting for guidance or a sense of direction from the FAA's Unmanned Aviation Systems Integrated (UASI) Office and its European counterpart, EASA. Any undue protraction in bringing out regulations is a detriment to all drone-related stakeholders, in utilizing to the fullest extent, the benefits of drone technology.

ICAO's standards for drones, 'once approved, [will] guide ICAO's member states in setting their own national regulations' ${ }^{64}$ ICAO's goal is to replace a patch-work of various national laws with a minimum uniform standard for drones. Although, it is ideal to wait until ICAO comes out with a universal standard, India could, in cooperation with its neighbors, formulate a common standard.

India has a large internal market for civilian drones and its applications, and potentially on the outside as well. In order to capitalize on this, the Indian DGCA must be proactive in enabling and playing a supportive role to the drone industry within the country and at the regional level. ICAO's annual 'Conference of Directors General of Civil Aviation Asia and Pacific Regions' would be great platform to discuss the possibility of creating a joint or common regulatory framework and/or standards for drones within this region. Further, India is party to the Charter of the South Asian Association for Regional Cooperation (SAARC), ${ }^{65}$ which encourages economic, social and technical cooperation in the region, between the eight State Parties ${ }^{66}$, ideally to complement bilateral and multilateral cooperation. ${ }^{67}$ Over the years, several areas of cooperation have been identified, for example, biotechnology, security, social development, etc,.

More particularly, at the $13^{\text {th }}$ SAARC Summit, ${ }^{68}$ importance was laid on cooperation in science and technology, wherein the member states agreed to 'meet the challenges of the twenty first century and to give priority attention to encourage regional cooperation in these areas to derive benefits from the synergy of collective, well-planned and focused initiatives undertaken by member states'. The regulatory challenge posed by drone technology is a topical and urgent issue that provides a compelling motive to commence concrete actions towards regional cooperation between the SAARC countries. A robust effort in this direction could lead to bloc level cooperation with other regional organizations such as ASEAN and beyond too.

Developing nations would derive the most benefits from the use of civilian drone technology, as it has been identified in many studies by agencies of the United Nations. ${ }^{69}$ Thus, resolving legal and regulatory issues and keeping in mind regional

${ }^{63}$ ICAO, "Integrating RPAS into Airspace," The ICAO Journal 70 No. 2 (2015): 4, accessed on 13 February 2016, http://www.icao.int/publications/journalsreports/2015/7002 en.pdf.

${ }^{64}$ Ibid.

65 Concluded on 8 December 1985. See "SAARC Charter" http://www.saarc-sec.org/SAARC-Charter/5/, accessed on 11 February 2016.

${ }^{66}$ Afghanistan, Bangladesh, Bhutan, India, Maldives, Nepal, Pakistan, and Sri Lanka.

${ }^{67}$ South Asian Association for Regional Cooperation Charter, charter signed in Dhaka, 8 December 1985, arts. 1 and 2.

${ }^{68}$ Being held in Dhaka, 13 November 2005.

69 Lindsey Harriman and Joseph Muhlhausen, “A New Eye in the Sky: Eco-drones," http://www.unep. 
peculiarities could work advantageous to all stakeholders, rather than blindly adopting regulations and standards. Further, such cooperation will pave the way for more advanced cooperation between the Asian countries in general civil aviation, which has till now been challenging and elusive.

\section{Conclusion}

The use of drone technology for civilian purposes is inevitable in the future. Nations in the Global South collectively face the greatest challenges of the millennium in the form of displacements, poverty, environmental problems, limited access to resources, etc. The use of drones has projected a promising future in addressing some of these challenges. Such possibilities, in addition to the ones identified by developed nations in advanced usage of drones, further prove that drones are here to stay, 'but we cannot forget the potential harms, such as the invasion of privacy, violation of intellectual property rights, and liability concerns surrounding this technology. ${ }^{\prime 70}$

Indonesia, India, and Thailand have responded to the proliferation of civilian drones in different ways as explained above. In each case, the response has been a reaction rather than a pro-active measure. They cannot be termed complete laws or regulations; they are works in progress. Yet, such measures are a display of efforts being taken towards accommodating a disruptive technology. To make the fullest use of this technology, adequate support must be given to the industry, which means that law making needs to be vigilant to the unique needs of this technology, for example, in defining and classifying drones as distinct from traditional aircraft; while at the same time be dynamic enough to accommodate future needs in this growing industry. In addition, sufficient measures must be taken to instill public confidence by protecting their freedoms and rights.

The way forward is challenging, for the regulators, policy makers and legislators. However, since this is common to all nations, there is a possibility in seeking a collective solution through regional cooperation. Such a solution may lead to stronger co-operation in other related fields as well. While formulating a regionally binding legal instrument is unrealistic, creating soft laws will be a step forward in creating regional uniformity.

The need of the hour is to find the right balance to the interests of all stakeholders and translating them into a beneficial legal and regulatory framework. Although the benefits to be reaped from drone use are numerous, excessive support to technology and economy, compromising on human, moral, and ethical values will prove harmful. 'The law must fill this gap. That is, after all, what the law is about, "providing human values in an age where technology causes both profound wonderment and profound disruption". ${ }^{71}$

\section{Acknowledgement}

The first author wishes to thank Indonesia Endowment Fund for Education

org/pdf/UNEP-GEAS MAY 2013.pdf, accessed on 11 February 2016. "Unmanned Aerial Vehicles in Humanitarian Response," http://www.elrha.org/wp-content/uploads/2015/01/Unmanned-Aerial-Vehiclesin-Humanitarian-Response-OCHA-July-2014.pdf, accessed on 11 February 2016.

${ }^{70}$ Katyal, loc.cit.

${ }^{71}$ Ibid. 
(Lembaga Pengelola Dana Pendidikan) - the Indonesian Ministry of Finance, the Republic of Indonesia for its scholarship and funding support for this research.

The second author wishes to thank R. Aswin Kumar for extending his support towards writing this paper.

\section{Bibliography}

\section{Legal Documents}

India, Constitution of India (1949).

-_- Directorate General of Civil Aviation Public Notice. No. 05-13/2014-AED (2014).

-_- Penal Code. Act No. 45 (1860).

Indonesia. Peraturan Menteri Perhubungan tentang Pengendalian Pengoperasian Pesawat Udara Tanpa Awak di Ruang Udara yang Dilayani Indonesia (Minister of Transportation Regulation regarding Unmanned Aerial Vehicle within the Indonesian Air Space). Permenhub No. 90 Tahun 2015, BNRI No. 723 ofYear 2015 (Minister Regulation No. 90 ofYear 2015, SG No. 723 ofYear 2015).

- - - Undang-Undang tentang Penerbangan (Law regarding Aviation). UU No. 1 Tahun 2009, LN No. 1 ofYear 2009 (Law No. 1, SG. No. 1 ofYear 2009).

South Asian Association for Regional Cooperation Charter. Dhaka, 8 December 1985. Thailand. Air Navigation Act. B.E. 2497 (1954).

- - - Announcement of Department of Transportation of Thailand on the Provisions and Conditions on Commanding and Releasing Pilotless Aircraft. B.E. 2558 (2015).

- - - Department of Transportation Regulation on non-Aircraft Object. B.E. 2548 (2005).

United Nations. International Covenant on Civil and Political Rights (1966).

-_- Universal Declaration of Human Rights (1948).

\section{Books}

de Beer, Lydia. Unmanned Aircraft Systems (Drones) and Law. Nijmegen: Wolf Legal Publishers, 2011.

Herrero, Álvaro et al. International Joint Conference SOCO'13-CISIS'13-ICEUTE'13, Salamanca, Spain, September 11th-13th, 2013 Proceedings. Basel, Springer International Publishing, 2014.

Lessig, Lawrence. Code and Other Laws of Cyberspace. New York: Basic Books, 1999.

Mueller, John and Mark G. Stewart. Terror, Security, and Money: Balancing the Risks, Benefits, and Costs of Homeland Security. Oxford: Oxford University Press, 2011.

\section{Articles}

Clarke, Roger. "Understanding the Drone Epidemic." Computer Law \& Security Review 30 (2014): 231-246. Accessed on 20 February 2016. doi: http://dx.doi. org/10.1016/j.clsr.2014.03.002.

Gogarty, Brendan and Meredith Hagger. "The Laws of Man Over Vehicles Unmanned: The Legal Response to Robotic Revolution on Sea, Land and Air." Journal of Law, Information and Science 19 (2008): 73-145. Accessed on 20 February 
2016. http://www.jlisjournal.org/content/Gogarty\%20and\%20Hagger\%20 ЈLIS\%2019.pdf.

ICAO. "Integrating RPAS into Airspace." The ICAO Journal 70 No. 2 (2015): 4. Accessed on 13 February 2016. http://www.icao.int/publications/ journalsreports/2015/7002 en.pdf.

Kaiser, Stefan A. "UAVs and Their Integration into non-Segregated Airspace." Air and Space Law 36, issue 2 (2011): 161-172.

Katyal, Neal. "Disruptive Technologies and the Law." Thee Georgetown Law Journal 102, issue 6 (2014): 1685-1689. Accessed on 20 February 2016. http:// georgetownlawjournal.org/files/2014/08/Katyal-Disruptive.pdf.

\section{Websites}

"ASEAN Open Skies Policy to be Implemented in 2015." http://www.aseanbriefing. com/news/2015/01/02/asean-open-skies-policy-implemented-2015.html. Accessed on 12 February 2016.

"Commercial Drones: Highways in the Sky, Unmanned Aerial Systems (UAS), Market Shares, Strategies, and Forecasts, Worldwide, 2015 to 2021." http:// www.rnrmarketresearch.com/commercial-drones-highways-in-the-skyunmanned-aerial-systems-uas-market-shares-strategies-and-forecastsworldwide-2015-to-2021-market-report.html. Accessed on 21 February 2016.

"Delhi Police to Use Drones for Street Surveillance." http://www.livemint.com/ Politics/judPhYHQsNw3T5p6iQgllN/Delhi-Police-to-use-drones-for-streetsurveillance.html. Accessed on 8 February 2016.

"Drohne "Luna": Bundeswehr verheimlichte Beinahe-Crash mit Airbus." http:// www. spiegel.de/politik/deutschland/drohne-luna-bundeswehr-verheimlichtbeinahe-crash-mit-airbus-a-903337.html. Accessed on 20 February 2016.

"Explore Terms: A Glossary of Common Cybersecurity Terminology." https://niccs.uscert.gov/glossary\#Spoofing. Accessed on 20 February 2016.

"List of Defence Items Requiring Industrial Licenses." http://dipp.nic.in/English/ acts_rules/Press_Notes/pn3_2014.pdf. Accessed on 22 February 2016.

"Permission Needed to Fly Drone in Public." http://www.thehindu.com/news/cities/ chennai/permission-needed-to-fly-drone-in-public/article6764693.ece. Accessed on 8 February 2016.

"SAARC Charter." http://www.saarc-sec.org/SAARC-Charter/5/. Accessed on 11 February 2016.

"UAV Regulations in India - A Pre - Requsite." http://www.usai.in/regulations.html. Accessed on 8 February 2016.

"Unmanned Aerial Vehicles in Humanitarian Response." http://www.elrha.org/ wp-content/uploads/2015/01/Unmanned-Aerial-Vehicles-in-HumanitarianResponse-OCHA-July-2014.pdf. Accessed on 11 February 2016.

"Unmanned Aerial Vehicle in Kedarnath to Help Rescue, Relief Operation: NDMA." http://articles.economictimes.indiatimes.com/2013-07-08/ news/404435331 uav-unmanned-aerial-vehicle-kedarnath. Accessed on 8 February 2016.

Amelia R, Mei. "Kembalikan Drone yang Jatuh di Menara BCA, Polisi: Sementara Rekaman Disita." ["Returning drone that fell in BCA tower, Police: Records will be temporary confiscated"]. http://news.detik.com/berita/2985250/ kembalikan-drone-yang-jatuh-di-menara-bca-polisi-sementara-rekamandisita. Accessed on 19 February 2016.

Angad, Abhishek and Sarah Hafeez. "Police Use Drones to Find Bricks, Bottles." http:// 
indianexpress.com/article/cities/delhi/police-use-drones-to-find-bricksbottles/. Accessed on 8 February 2016.

Brummitt, Chris and Hendaru Purnomo. "Indonesia is Using Drones to Catch Tax Cheats." https://www.bloomberg.com/news/articles/2015-06-03/dronesseek-out-tax-cheats-in-indonesia-s-palm-oil-plantations. Accessed on 3 February 2016.

Center for the Study of the Drone. "Drones in Southeast Asia." http://dronecenter. bard.edu/drones-in-southeast-asia/. Accessed on 1 February 2016.

Clarke, Roger. "Understanding the Drone Epidemic." https://www.parliament.nsw. gov.au/prod/parlment/committee.nsf/0/f618f4da91a21907ca257c86001a3 31b/\$FILE/Article\%20-\%20Understanding\%20the\%20Drone\%20Epidemic. pdf. Accessed 23 January 2016.

Daly, Angela and Steve Collins. "Disruption and the Law." http://peerproduction.net/ issues/issue-6-disruption-and-the-law/. Accessed on 20 February 2016.

Dixit, Pranav. "Something in the Air: Drones Finally Making a Comeback to Indian Skies." http://www.hindustantimes.com/tech/something-in-the-air-drones-finallymaking-a-comeback-to-indian-skies/story-Ka0UCL1nwB90NoRU4Nuw4M. html. Accessed on 8 February 2016.

Hall, Joseph Lorenzo. "'License Plates' for Drones." https://cdt.org/blog/licenseplates-for-drones/. Accessed on 20 February 2016.

Harriman, Lindsey and Joseph Muhlhausen. "A New Eye in the Sky: Eco-drones." http://www.unep.org/pdf/UNEP-GEAS_MAY2013.pdf. Accessed on 11 February 2016.

Krishnamurthy, Krithika. “India to be Launch Pad for Amazon's Plan to Deliver Packages Using Drones; Deliveries May Start by Diwali." http://articles.economictimes. indiatimes.com/2014-08-20/news/53028827 1 prime-air-drones-outdoorsamazon. Accessed on 8 February 2016.

Lamb, Kate. "Indonesia Readies Mass Production of Drones, Voice of America." http://www.voanews.com/content/indonesia-readies-mass-production-ofdrones/1651633.html. Accessed on 20 February 2016.

Ledysia, Septiana. "Polisi: Jika Ada Pelanggaran, OX Pemilik Drone Bisa Dipidana." ["Police: If there is any offence, OX, drone owner can be criminally charged"]. http://news.detik.com/berita/2983492/polisi-jika-ada-pelanggaran-oxpemilik-drone-bisa-dipidana. Accessed on 19 February 2016.

Lee Pei Qi, Paige and Rosa Ocampo. "ASEAN Open Skies Impeded by Limited Landing Slots." http://www.ttgasia.com/article.php?article id=26522. Accessed on 10 February 2016.

Nugraha, Ridha Aditya. "Fenomena Drone: Tantangan Baru bagi Hukum Udara Indonesia." http://www.hukumonline.com/berita/baca/lt569601b5795dc/ fenomena-drone--tantangan-baru-bagi-hukum-udara-indonesia-broleh-ridha-aditya-nugraha-. Accessed on 26 January 2016.

Office of the Director-General of Civil Aviation, India. http://dgca.nic.in $/ \mathrm{misc} /$ draft\%20circular/AT_Circular\%20-\%20Civil_UAS(Draft\%20April\%202016). pdf. Accessed on 6 June 2016.

Rajput, Rashmi. "Mumbai Police Seeks Explanation on Drone Pizza Delivery." http:// www.thehindu.com/news/cities/mumbai/mumbai-police-seeks-explanationon-drone-pizza-delivery/article6043644.ece. Accessed on 8 February 2016.

Sharma, Vishal. “Jharkhand's Tiger Reserve to Use Drones for Surveillance." http:// www.hindustantimes.com/india/jharkhand-s-tiger-reserve-to-use-dronesfor-surveillance/story-TfxduW3x546TzuUkr8dezJ.html. Accessed on 8 February 2016. 
Singh, Alok. "Delhi Police Work on SOP for Use of Drones.” http://indianexpress.com/ article/cities/delhi/delhi-police-work-on-sop-for-use-of-drones/. Accessed 8 February 2016.

Sterling, Toby. "Dutch Police Train Eagles to Snatch Enemy Drones." http://www. reuters.com/article/us-dutch-police-drones-idUSKCN0VB136. Accessed on 11 February 2016.

Wapner, Jessica. "Medical Transport Drones Could Transform Healthcare in Overcrowded Cities." http://europe.newsweek.com/india-organ-transplantdrones-419013?rm=eu. Accessed on 8 February 2016.

\section{Workshop}

"RPAS/UAS: A Challenge for International, European, and National Air Law." Workshop of EASA and Institute of Air and Space Law held at University of Cologne (23-24 May 2013). 